\title{
RADIATION USE EFFICIENCY, ABOVE GROUND BIOMASS ACCUMULATION, CANOPY DEVELOPMENT, LEAF AREA-LIGHT INTERCEPTION PROFILES AND RADIATION INTERCEPTION OF SUNFLOWER (Helianthus annuus L.) AS INFLUENCED BY IRRIGATION REGIMEN
}

S. Sridhara ${ }^{1^{*}}$ and T.G. Prasad ${ }^{2}$

${ }^{1}$ Agricultural Research Station, Babbur farm post, Hiriyur 572 143, Chitradurga, India

${ }^{2}$ Department of Crop Physiology, University of Agricultural Sciences,

G.K.V.K., Bangalore 560 065, India

Received: September 13, 2000

Accepted: September 04, 2001

SUMMARY

A field experiment was conducted at Gandhi Krishi Vignana Kendra, University of Agricultural Sciences, Bangalore to study the effect of irrigation regimens on the biomass accumulation, canopy development, light interception and radiation use efficiency of sunflower. The treatments includes irrigating the plants at $0.4,0.6,0.8$ and 1.0 cumulative pan evaporation. The results indicated that the aboveground biomass, canopy development, radiation interception and radiation use efficiency were influenced favorably by the irrigation regimens. Irrespective of the irrigation regimen, the radiation use efficiency of sunflower increased from 15 DAS to 75 DAS and then tended to decline. The decrease in RUE after anthesis is coupled with decrease in leaf nitrogen content. In general the RUE of sunflower ranged from $0.49 \mathrm{~g} \mathrm{MJ}^{-1}$ to $1.84 \mathrm{~g} \mathrm{MJ}^{-1}$ at different growth stages. The light transmission within the canopy increased exponentially with plant height and the canopy extension coefficient is found to be 0.8 .

Key words: radiation use efficiency, radiation interception, canopy development, canopy extinction coefficient and irrigation regimen

\section{INTRODUCTION}

Dry matter production of crops may be simulated as a fraction of the time-integrated product of the daily incident photosynthetically active radiation (PAR), the fraction of PAR intercepted by the canopy, and the radiation use efficiency (RUE)

* Corresponding author 
(Monteith,1977). Several simulation models use this concept to predict the dry matter production of crops under nonstressed conditions ( ones and Kiniry, 1986; Kiniry et al., 1992). Several attempts have been made to estimate the RUE of sunflower (Connor et al., 1985; Cox and J olliff, 1986; Tripani et al., 1992; Chapman el al., 1993; Steer et al., 1993). Earlier studies reported that the RUE of sunflower is sometimes constant from emergence to maturity and sometimes greater before anthesis than during grain filling. No attempts were made to study the influence of irrigation regimes on RUE of sunflower. Hence, the objectives of this study were to examine the effect of irrigation regimens on light interception, canopy development, aboveground biomass accumulation and RUE of sunflower.

\section{MATERIALS AND METHODS}

A field experiment was conducted during the summer season of 1994 at Gandhi Krishi Vignana Kendra, University of Agricultural Sciences, Bangalore. The soil was a sandy loam of medium fertility with $\mathrm{pH}$ of 5.60 . The soil contains about $189.0 \mathrm{~kg}$ ha ${ }^{-1}$ of available $\mathrm{N}, 18.3 \mathrm{~kg} \mathrm{ha}^{-1}$ of Bray's $\mathrm{P}_{2} \mathrm{O}_{5}$ and $224.0 \mathrm{~kg} \mathrm{ha}^{-1}$ of exchangeable $\mathrm{K}_{2} \mathrm{O}$. The treatments included were four irrigation regimes viz., weekly irrigation amounting to $0.4,0.6,0.8$ and 1.0 cumulative pan evaporation (CPE). The experiment was laid out as randomized block design with four replicates. The sunflower CV. KBSH-1 was sown following a spacing of $60 \times 30 \mathrm{~cm}$ and regular cultivation practices were followed.

\section{Collection of data}

The data on total aboveground biomass and leaf area were recorded at fifteenday intervals from 15 days after sowing. The leaf area was measured using leaf area meter (LiCOR-3000). Photosynthetically active radiation (PAR) intercepted by the canopy was determined by a line quantum sensor of one meter length (LiCOR, USA). In each plot one measurement was obtained above the canopy and five measurements were made at ground level. At 60 DAS the entire canopy was divided into five profiles based on plant height and the leaf area and light transmission (\%) was measured for each profile. To eliminate the effect of solar elevation on PAR interception, all measurements were confined to the mid-day period only (12 noon-1.30 PM). Solar radiation intercepted by the canopy is reported as percentage of the total available PAR at the top of the canopy. Light extinction coefficient $(\mathrm{k})$ was computed as $k=\ln \left(I / I_{0}\right) / L A I$, where I is the PAR values below the canopy, $I_{0}$ is the PAR values above the canopy and LAl is the leaf area index.

The amount of solar radiation was calculated by following the ASTRO sub routine of the ORYZA model described by Drenth et al., 1995. The total incoming solar radiation (cal $\mathrm{cm}^{-2}$ day $^{-1}$ ) was converted to PAR (MJ $\mathrm{m}^{-2}$ day ${ }^{-1}$ ) using a conversion constant of 0.042 , and assuming $45 \%$ of incoming radiation energy as PAR (Monteith, 1965; Meek et al., 1984; Kiniry et al., 1989). Radiation use efficiency was cal- 
culated by regressing the intercepted PAR versus aboveground biomass as suggested by Gallo et al. (1993).

\section{RESULTS AND DISCUSSION}

The pattern of aboveground biomass accumulation with time for different irrigation regimes is shown in Figure 1.

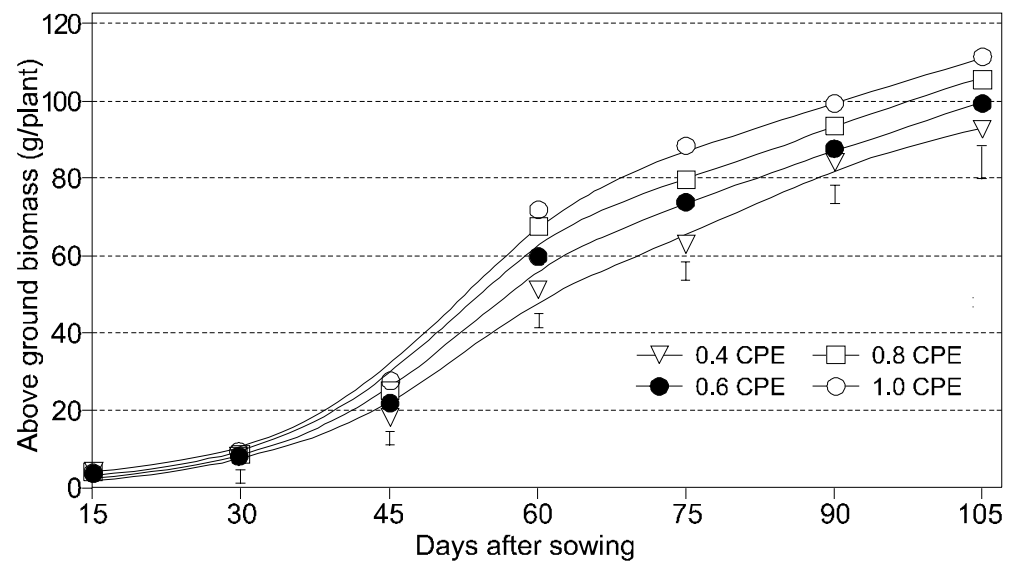

Figure 1: Aboveground biomass accumulation as influenced by irrigation regimen. Vertical bars indicate the critical difference $(p=0.05)$

It can be inferred from Figure 1 that the aboveground biomass in sunflower was positively influenced by the irrigation regimens and followed a sigmoid pattern. An increase in total biomass to an extent of $22 \%$ was noticed due to increase in irrigation regimen from 0.4 to $0.8 \mathrm{CPE}$. The results agree with the findings of Merrien et al. (1982). The differences in the aboveground biomass accumulation may be due to the fact that the plants that received the higher levels of irrigation (1.0 CPE) intercepted a larger amount of PAR (Table 1).

Table 1: Leaf area ( $\left.\mathrm{cm}^{2} / p l a n t\right)$ at different growth stages as influenced by irrigation regimen

\begin{tabular}{lccccccc}
\hline \multirow{2}{*}{ Irrigation regimen } & \multicolumn{7}{c}{ Days after sowing } \\
\cline { 2 - 8 } & 15 & 30 & 45 & 60 & 75 & 90 & Harvest \\
\hline $0.4 \mathrm{CPE}$ & 153.20 & 815.50 & 1545.50 & 3327.00 & 3454.00 & 903.14 & 128.32 \\
$0.6 \mathrm{CPE}$ & 165.20 & 846.50 & 1678.00 & 3532.50 & 3659.00 & 945.14 & 164.44 \\
$0.8 \mathrm{CPE}$ & 168.80 & 874.50 & 1963.00 & 3665.50 & 3814.00 & 983.22 & 179.60 \\
1.0 CPE & 174.80 & 914.00 & 2190.00 & 3829.50 & 3945.50 & 1032.64 & 204.08 \\
F-test & $*$ & $*$ & $*$ & $*$ & $*$ & $*$ & $*$ \\
S.Em \pm & 1.97 & 7.27 & 11.52 & 43.74 & 51.66 & 9.96 & 3.20 \\
C.D. at 5\% & 6.08 & 22.42 & 35.51 & 134.79 & 159.19 & 30.68 & 9.86 \\
\hline
\end{tabular}


The amount of PAR interception by sunflower ranged from 56.34 to $516.48 \mathrm{MJ}$ $\mathrm{m}^{-2}$ by the plants irrigated at $0.4 \mathrm{CPE}$ and from 59.40 to $526.99 \mathrm{MJ} \mathrm{m} \mathrm{m}^{-2}$ by the plant irrigated at 1.0 CPE. Irrespective of the irrigation regimen the PAR interception increased from 15 DAS to 75 DAS and then tended to decline. The differences in PAR interception may be attributed to differences in the canopy development (Table 2).

Table 2: Cumulative intercepted photosynthetically active radiation (MJ) at different growth stages as influenced by irrigation regimen

\begin{tabular}{lccccccc}
\hline \multirow{2}{*}{ Irrigation regimen } & \multicolumn{7}{c}{ Days after sowing } \\
\cline { 2 - 8 } & 15 & 30 & 45 & 60 & 75 & 90 & Harvest \\
\hline 0.4 CPE & 56.34 & 157.88 & 247.19 & 389.45 & 516.48 & 480.29 & 292.58 \\
0.6 CPE & 56.08 & 159.63 & 252.02 & 393.27 & 521.13 & 486.61 & 323.56 \\
0.8 CPE & 58.55 & 161.17 & 216.04 & 395.52 & 524.41 & 492.09 & 335.07 \\
1.0 CPE & 59.40 & 163.24 & 267.14 & 398.13 & 526.99 & 498.88 & 352.31 \\
F-test & $*$ & $*$ & $*$ & $*$ & $*$ & $*$ & $*$ \\
S.Em \pm & 0.29 & 0.42 & 0.37 & 0.88 & 1.15 & 1.50 & 2.53 \\
C.D.at 5\% & 0.90 & 1.29 & 1.12 & 2.72 & 3.56 & 4.65 & 7.82 \\
\hline
\end{tabular}

Plants irrigated at 1.0 CPE produced greater leaf area than the plants irrigated at lower levels of irrigation, therefore had greater PAR interception. Rawson and Turner (1982) and Takami et al. (1982) also observed similar trends in canopy expansion of sunflower. An attempt was also made to study the leaf area-light interception profiles of sunflower. The results indicated that irrespective of irrigation regimen, the sunflower displayed most of it leaf area in the middle of its height and the light transmission increased exponentially with plant height (Figure 2).

Table 3: Least square regressions fitted to describe the relationship between cumulative photosynthetically active radiation intercepted by the canopy and total above ground biomass

\begin{tabular}{lcccc}
\hline \multirow{2}{*}{ Irrigation regimen } & \multicolumn{4}{c}{ Regression parameter } \\
\cline { 2 - 5 } & $\mathrm{a}$ & $\mathrm{b}$ & $\mathrm{c}$ & $\mathrm{R}^{2}$ \\
\hline $0.4 \mathrm{CPE}$ & -91.28 & 0.98 & 0.0011 & 0.86 \\
& -30.39 & 0.37 & & 0.89 \\
$0.6 \mathrm{CPE}$ & -97.86 & 1.07 & 0.0012 & 0.92 \\
& -35.99 & 0.45 & & 0.94 \\
$0.8 \mathrm{CPE}$ & -103.54 & 1.14 & 0.0011 & 0.92 \\
& -43.92 & 0.55 & & 0.93 \\
$1.0 \mathrm{CPE}$ & -113.40 & 1.23 & 0.003 & 0.93 \\
& -36.67 & 0.47 & & 0.95 \\
\hline
\end{tabular}

Radiation use efficiency was calculated using aboveground biomass and cumulative IPAR for different irrigation regimens. Fitted regressions describing the relationship between cumulative IPAR and aboveground biomass (Table 3) provided accurate description of the data obtained in all treatments. Instantaneous values of RUE were derived for various sampling dates during crop growth by taking derivatives of least-square quadratic regression fitted to aboveground biomass and cumu- 
lative IPAR for each irrigation regimen. The aboveground biomass at final harvest stage was not considered for calculation of RUE due to the uncertainty in extrapolation and also possible confounding effects of maturity, crop growth rate and RUE (Bell et al., 1992). Estimates of RUE were ther efore derived from 15 to 90 DAS for all treatments.
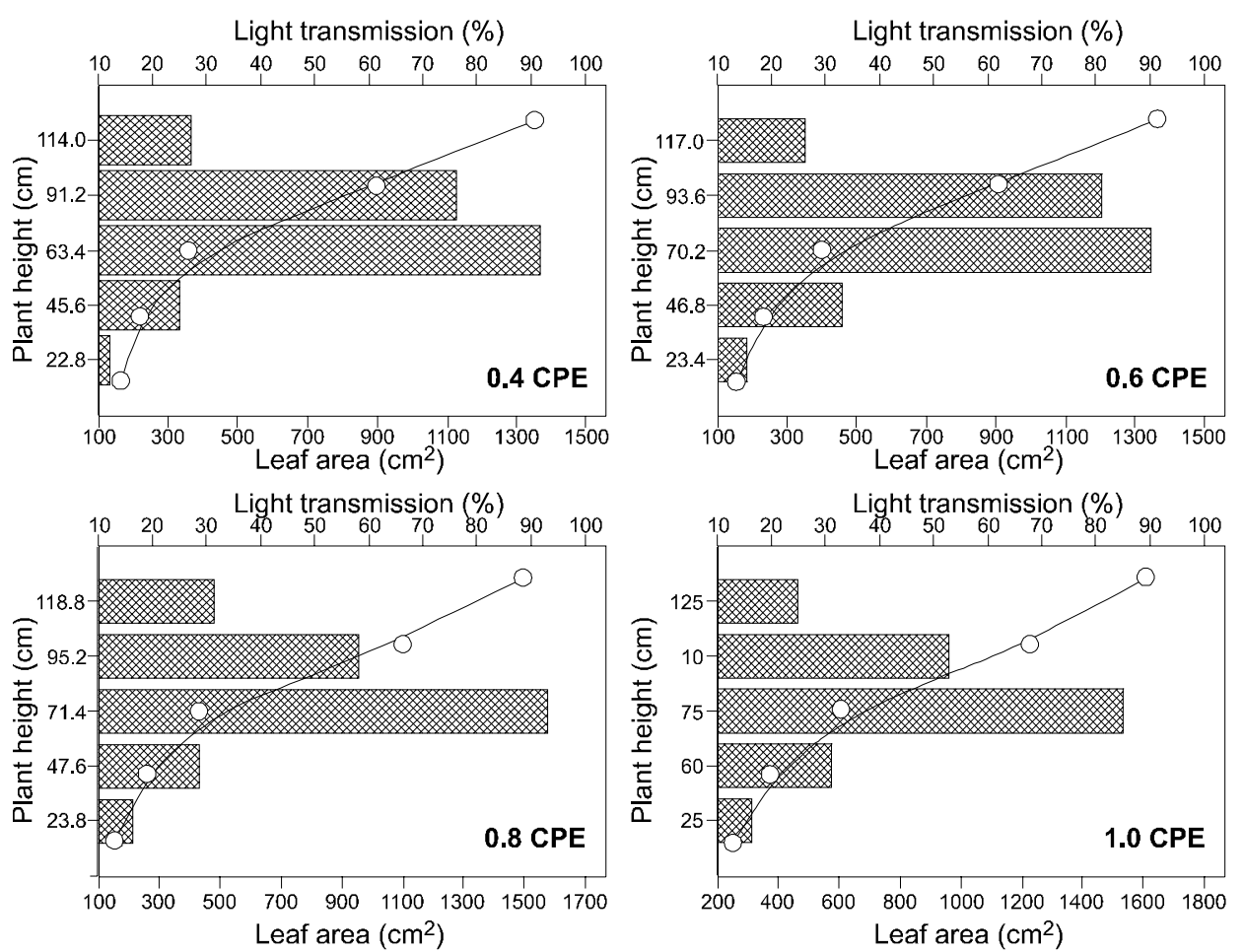

Figure 2: Leaf area-light transmission profiles of sunflower as influenced by irrigation regimen

Irrespective of the irrigation regimen, the RUE increased from 15 DAS to 75 DAS and tended to decline (Figure 3). Similar trends in RUE for sunflower were also reported by Chapman et al. (1993) and Steer et al. (1993). Among irrigation regimes the RUE was highest with plants irrigated at $1.0 \mathrm{CPE}\left(0.62\right.$ to $\left.1.84 \mathrm{~g} \mathrm{MJ}^{-1}\right)$ and it was lowest with plants irrigated at $0.4 \mathrm{CPE}\left(0.49\right.$ to $\left.1.51 \mathrm{~g} \mathrm{MJ}^{-1}\right)$. The estimated values of RUE were in conformity with the estimated values for sunflower (Trapani et al., 1992; Steer et al., 1993; Flenet and Kiniry, 1995). The decrease in RUE after 75 DAS may be attributed to decrease in leaf nitrogen content from 75 DAS onwards (Figure 4). Other factors may also explain the decrease in RUE after anthesis, such as saturation of canopy photosynthesis associated with reduced leaf area, light interception by sunflower heads or increased maintenance respiratory losses due to greater temperatures (Flenet and Kiniry, 1995). 


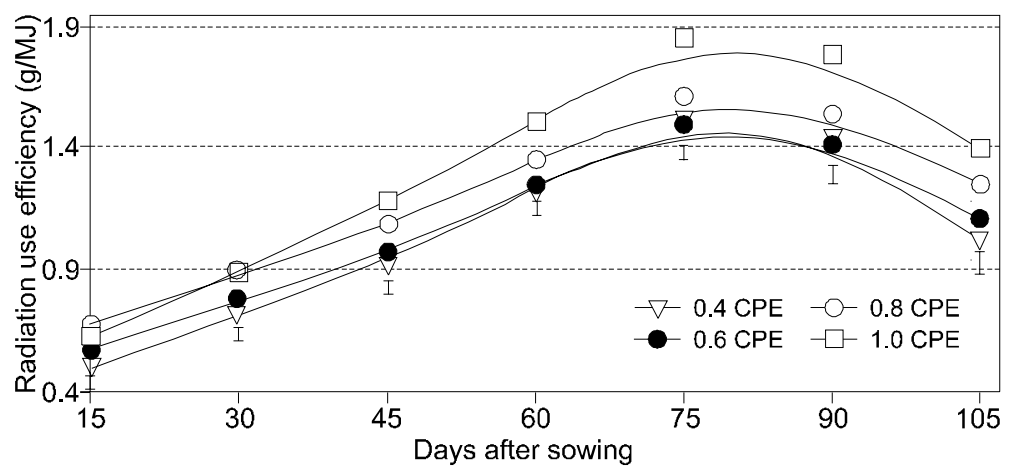

Figure 3: Radiation use efficiency of sunflower as influenced by irrigation regimen. Vertical bars indicate the critical difference $(p=0.05)$

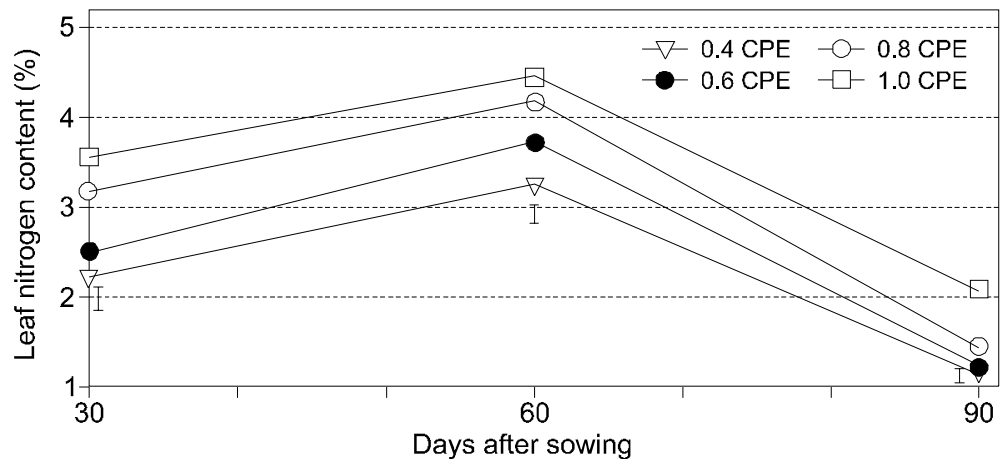

Figure 4: Leaf nitrogen content as influenced by irrigation regimen. Vertical bars indicate the critical difference $(p=0.05)$

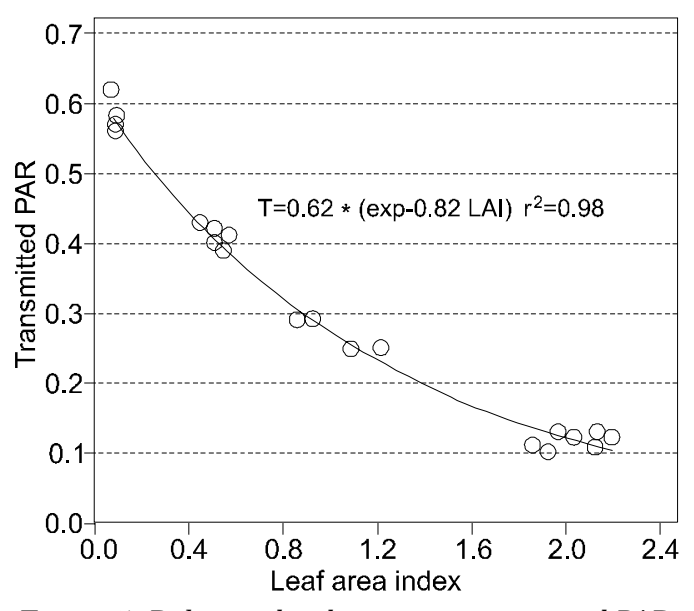

Figure 5: Relationship between transmitted PAR and leaf area index
An attempt was also made to calculate the light extinction coefficient of sunflower by regressing light interception against LAl (Figure 5). The results indicated that the light extinction coefficient for sunflower was 0.8 . The values of $k$ reported in this paper are in accordance with the values of $k$ reported for sunflower by Lemeur (1973) and Steer et al. (1993).

Based on this study it can be concluded that the RUE of sunflower is influenced positively by irrigation regimen. Irrespective of the irriga- 
tion regimen, the RUE of sunflower tends to decline from 75 DAS till maturity, and the baseline values of the RUE reported here can be used in realistic simulation of the sunflower biomass under different irrigation regimens. The light transmission within the canopy increased exponentially with plant height.

\section{ACKNOWLEDGMENTS}

The financial assistance in the form of Senior Research Fellowship to the author during his Ph.D. study from Council for Scientific and Industrial Research, New Delhi, is gratefully acknowledged.

\section{REFERENCES}

Bell, M.J ., Wright, G.C. and Hammer, G.L., 1992. Night temperature effects on radiation use efficiency in peanut. Crop Sci., 32: 1329-1335.

Chapman, S.C., Hammer, G.L. and Meinke, H., 1993. A sunflower simulation model: I model development. Agron. J ., 85: 725-735.

Connor, D.J ., J ones, T.R. and Palta, J.A., 1985. Response of sunflower to strategies of irrigation. I Growth, yield and efficiency of water use. Field Crops Research, 10: 15-36.

Cox, W.J . and J olliff, G.D., 1986. Growth and yield of sunflower and soybean under soil wates deficits. Agron. J ., 78: 226-230.

Drenth, H., ten Berge, H.F.M. and Riethoven, J .J .M., 1994. Description of ORYZA-N modules, P.7-42. In: ORYZA simulation models for potential and nitrogen limited rice production. SARP Research Proceedings, DLO-Research Institute for Agrobiology and Soil Fertility, Wageningen, The Netherlands.

Flenet, F. and Kiniry, J .R., 1995. Efficiency of biomass accumulation by sunflower as affected by glucose requirement of biosynthesis and leaf nitrogen content. Field Crops Research, 44: 119-127.

Gallo, K.P., Daughtry, C.S.T. and Wiegand, C.L., 1993. Errors in measuring absorbed radiation and computing crop radiation use efficiency. Agron J ., 85:1222-1228.

J ones, C.A. and Kiniry, J .R., 1986. Ceres maize: A simulation model for maize growth and development. Texas A\&M University Press, College Station, USA.

Kiniry, J .R., J ones, C.A., Toole, J .C., Blanchet, R., Cabelguenne, M. and Spanel, D.A., 1989. Radiation use efficiency in biomas accumulation prior to grain filling for five grain crop species. Field Crops Research, 20: 51-64.

Kiniry, J .R., Blanchet, R., Williams, J .R., J exig, V., J ones, C.A. and Cabelquenne, M., 1992. Sunflower simulation using EPIC and ALMANAC models. Field Crops Research, 30: 403423.

Lemeur, R., 1973. A method for simulating the direct solar radiation regimen in sunflower, $J$ erusalem artichoke, corn and soybean canopies using actual stand structure data. Agric. Meterol., 12: 229-247.

Meek, D.W., Hatfield, J .L., Howell, T.A., Idso, S.D. and Reginato, R.J ., 1984. A generalized relationship between photosynthetically active radiation and solar radiation. Agron. J ., 76: 939-945.

Merrien, A., Blanchet, R., Geffi, No., Rollir, J .P. and Rokit, M., 1982. Pathway of yield elaboration in sunflower under various water stresses. In: Proc. $10^{\text {th }}$ International Sunflower Conference, Australia, Field Crops Abstr., 36: 886.

Monteith, J .L., 1965. Radiation and crops. Exp. Agric., 1: 241-251.

Monteith, J .L., 1977. Climate and the efficiency of crop production in Britain. Philop. Trans. R. Soc. London, B., 281: 277-329.

Rawson, H.M. and Turner, N.C., 1982. Recovery from water stress in five sunflower cultivars. II Development of leaf area. Aust. J . Plant Physiology, 9: 449-460.

Steer, B.T., Milroy, S.P. and Kamona, R.M., 1993. A model to simulate the development, growth and yield \& irrigated sunflower. Field Crops Research, 32: 83-99. 
Takami, S., Rawson, H.M. and Turner, N.C., 1981. Leaf expansion of four sunflower cultivars in relation to water deficits. II Diurnal pattern during stress and recovery. Plant Cell Environ., 5: 279-286.

Trapani, N., Hall, A.J ., Sadras, V.O. and Vilella, F., 1992. Ontogenetic changes in radiation use efficiency of sunflower crops. Field Crops Research, 29: 301-316.

\author{
INFLUENCIA DEL RÉGIMEN DE IRRIGACIÓN SOBRE LA \\ EFICACIA DEL USO DE LA RADIACIÓN, LA \\ ACUMULACIÓN DE BIOMASA, EL DESAROROLLO DEL \\ CANOPEO, EL ÁREA DE LA HOJ A Y LOS PERFILES DE \\ INTERCEPCIÓN DE LUZ Y DE RADIACIÓN EN GIRASOL \\ (Helianthus annuus L.) \\ RESUMEN
}

Un experimento a campo se realizó en "Gandhi Krishi Vignana Kendra", Universidad de Ciencias Agrícolas, de Bangalore, a los efectos de estudiar los regímenes de irrigación sobre la acumulación de biomasa, el desarrollo del canopeo, la interceptación de luz y la eficiencia del uso de la radiación en girasol. Los tratamientos incluyeron el riego de las plantas a las $0,4,0,6,0,8$ y 1,0 evaporación acumulativa pan. Los resultados indicaron que la biomasa por encima del suelo, el desarrollo del canopeo, la intercepción de la radiación y la eficiencia del uso de la radiación fueron influenciados favorablemente por los regímenes de riego. Independientemente del régimen de irrigación, la eficiencia de uso de la radiación en el girasol aumentó de 15 DAS a 75 DAS y luego tendió a disminuir. La disminución en "RUE" después de antesis está asociada a la disminución del contenido de nitrógeno de hoja. En general la "RUE" de girasol fue de $0,49 \mathrm{~g} \mathrm{MJ}^{-1}$ a $1,84 \mathrm{~g} \mathrm{MJ}^{-1}$ en los diferentes estadios de desarrollo. La transmisión de luz dentro del canopeo aumentó exponencialmente con la altura de la planta y el coeficiente de extensión del canopeo fue 0,8 .

\author{
EFFICACITÉ DE L'UTILISATION DES RADIATIONS \\ SOLAIRES, ACCUMULATION DE LA BIOMASSE DANS LA \\ PARTIE AÉRIENNE, DÉVELOPPEMENT DE L'OMBRELLE, \\ PROFILS D'INTERCEPTION DE LA LUMIĖRE PAR LA \\ FEUILLE ET INTERCEPTION DES RADIATIONS SOLAIRES \\ CHEZ LE TOURNESOL (Helianthus annuus L.) SOUS \\ L'INFLUENCE D'UN RÉGIME D'IRRIGATION
}

RÉSUMÉ

Une expérience a été menée dans les champs de l'université des sciences agronomiques Gandhi Krishi Vignana dans le but d'étudier les effets des systèmes d'irrigation sur l'accumulation de la biomasse, le développement de l'ombrelle, l'interception de la lumière et l'efficacité de l'utilisation des radiations solaires chez le tournesol. Les traitements comprenaient une irrigation des plantes à des niveaux de $0.4,0.6,0.8$ et 1.0 d'évaporation cumulative du 
récipient. Les résultats obtenus ont démontré que les régimes d'irrigation étudiés avaient une influence positive sur la biomasse aérienne, le développement de l'ombrelle, l'interception d'énergie lumineuse et l'efficacité de l'utilisation des radiations solaires. Quel qu'ait été le régime d'irrigation, l'efficacité de l'utilisation de l'énergie solaire a augmenté de 15 à 75 jours après les semailles pour diminuer ensuite. La diminution de l'efficacité de l'utilisation de l'énergie solaire après l'anthèse était accompagnée d'une diminution du contenu d'azote dans les feuilles. En général, l'efficacité de l'utilisation de l'énergie solaire chez le tournesol s'étendait de $0.49 \mathrm{~g} \mathrm{MJ}^{-1}$ à $1.84 \mathrm{~g} \mathrm{MJ}^{-1}$ dépendant de la phase du développement. La transmission de la lumière entre les couches des feuilles augmentaient exponentiellement avec la taille de la plante et le coefficient du développement de l'ombrelle était de 0.8 . 
